Article

\title{
The Power of Carl Schmitt: Fascism, Dualism and Justice ${ }^{\dagger}$
}

\section{Richard A. Cohen}

Department of Jewish Thought, University at Buffalo (SUNY), Buffalo, NY 14260, USA; racohen@buffalo.edu + An earlier version of the present paper was first given as a keynote address at the 13th annual meeting of the North American Levinas Society held at Western Carolina University on 3 August 2018. I want to thank the National Endowment of the Humanities for their financial sponsorship of my attendance at that meeting of NALS, and for their earlier financial support of the Summer Seminar for Colleges and University Teachers held at the University at Buffalo, 17-21 July 2017, on the topic of "Emmanuel Levinas on Morality, Justice and the Political", where the same ideas were discussed before a different but no less dedicated cohort of scholars.

Received: 29 November 2018; Accepted: 17 December 2018; Published: 24 December 2018

check for updates

\begin{abstract}
The purpose of this paper is to show that underlying Schmitt's account of fascist politics lies a Gnostic-like metaphysical dualism separating the realms of value and power. Contrary to the normative political tradition of the West, which defends ethical politics, Schmitt-jurist and theorist of the Nazis-aligns himself with Machiavelli and Hobbes to defend realpolitik for which sovereignty is ultimately a function of the Dictator's will alone. This paper shows the contradiction within such a position, which criticizes values in politics, but by its advocacy and its defense of the Dictator's willing, relies on valuation, choice and hence, the ethical.
\end{abstract}

Keywords: justice; fascism; Nazi; Gnosticism; power; ethics; will

To robbery, butchery, and rapine, they give the lying name of "government"; they create a desolation and call it peace.

Publius Cornelius Tacitus, Agricola, 30

The exaltation of sacrifice for the sake of sacrifice, faith for the sake of faith, energy for the sake of energy, fidelity for the sake of fidelity, fervor for the heat it procures, the call to a gratuitous - that is to say, heroic - act: this is the permanent origin of Hitlerism.

Emmanuel Levinas, Difficult Freedom, p. 149

\section{Introduction: Fascism}

This paper addresses the thought of Carl Schmitt (1888-1985), Nazi jurist and political theorist, because despite its ultimate incoherence it represents one of the most sophisticated and rigorous philosophical defenses of fascism. ${ }^{1}$

What is fascism? Like all political regimes it lacks a precise definition, not only because of variety within type, or because it continues to evolve, but because politics is not a science. To be sure, politics ignores facts, truth and logic at its peril, but its core lies deeper, with purposes, values, deliberation and choice. But it is beyond these considerations that fascism is especially slippery, because it is essentially slippery, unmoored from logic and reason, or rather, as one might say today, paradoxically, with a logic

1 Schmitt's preeminence-or infamy—as a fascist theorist is already recognized by Franz Neumann in his justly celebrated 1942 study of the Nazis, Behemoth (Neumann 2009, pp. 49, 152). 
and reason of its own. Nonetheless, mindful of its two most influential historical instances, Mussolini's Fascist Italy and Hitler's Nazi Germany, fascism is recognizable by the following features, the first being the weightiest. (1) Supremacy of a Dictator, an autocratic ${ }^{2}$ Volk leader whose current decisions are taken as dictates to be obeyed by all as the will of all (Rousseau's "general will"). The Dictator's will is law, without appeal. (2) Primacy of resoluteness and action over debate and ideation; primacy of force, violence, manliness, patriarchy and misogyny; as was said in fascist Spain: "Death to Intelligence"3. (3) Myth of national greatness, past, present and future; invention of supportive history; doublespeak; Mussolini: "Our myth is the nation; our myth is the greatness of the nation"4 . (4) Statism, one-party rule, mass obedience and conformism. (5) Self victimization, fantastic conspiracies, all problems blamed on constructed alien others to justify compensatory internal surveillance, Gulags and external expansionist wars.

For obvious reasons, then, fascism is less a theory or idea than a mass movement of individuals united in obedience and feeling, as willing sacrificial instruments of the Dictator. Its basis is power, not reason, and as will to power, without goal or end, is always will to more power, like a shark always on the move, insatiably expansionist until bursting, inevitably self-annihilating, a Götterdämmerung, ${ }^{5}$ an Armageddon, dragging everything into an all-consuming vortex of sound and fury simulating greatness but signifying nothing. It is a truly berserk politics, appealing to the basest passions of human fear and self-assertiveness. No wonder, then, in order to install itself, fascism exacerbates or creates a social-political-economic environment of disruption, confusion, instability, and even terror, in which usually level-headed adults are driven to despair and like frightened children cry out for a Savior-especially one with simple solutions and firm resolve. Thus, the fascist Dictator creates a need for fascism, the conditions of his own necessity and the theatre for his own alleged greatness.

\section{Violence and Political Nihilism}

Just as Machiavelli conceived his political theories during the wars of Italian city-states, and Hobbes wrote Leviathan during the English Civil War, Schmitt developed his fascist political thought in the agitated world of Germany in the early 1920s, the enervated and turbulent post-Great War milieu of a devastated Europe and a fledgling Weimer Republic. The Bolsheviks under Lenin had militantly commandeered the February 1917 Russian Revolution in October of 1917, and under Trotsky's military command were fighting a brutal Civil War. A defeated Germany signed an Armistice 11 November 1918, and a few days later the Bavarian Soviet Republic declared its independence in Munich and was overthrown militarily a few months later in 1919 by a voluntary Freikorps army. In 1919, Berlin's workers revolted and were violently suppressed. In April of the same year, the two most brilliant Democratic Socialist leaders and theorists, Rosa Luxemburg and Karl Liebknecht, were abducted and bludgeoned to death by right wing thugs. Hundreds of other lesser-known political agitators, almost all of the left, were assassinated or jailed. Fascist black shirts threatened to march on Rome in October 1922, and the king handed the Italian government to their leader, Mussolini, by month's end. Thus, like Machiavelli and Hobbes, it was during no less fractious and perilous times (Hitler's failed putsch in Munich occurred on 26 September 1923) that Schmitt honed and elaborated his legal and political theories in several volumes appearing in a four year burst of productivity: Political Romanticism (1919), Dictatorship (1921), Political Theology (1922), and The Crisis of Parliamentary Democracy (1923), as well as additional shorter journal articles. A few years later, on the threshold of the Nazi takeover of Germany, and only one year before joining the Nazi party himself,

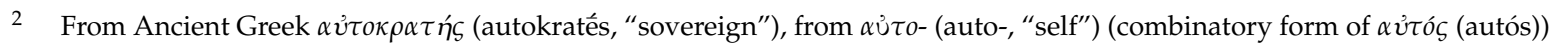

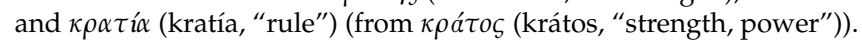

See (Weiss 1967, p. 99).

(ibid., p. 13).

Hitler from the start conceived his monumental architectural constructions, like his inevitable defeat, with an eye to how they would look as ruins, in memory. See, the final chapter, "The Choreography of the End," of Johann Capoutot's excellent and illuminating study (Capoutot 2016, pp. 357-91). 
he published The Concept of the Political (1932), which further elaborated and deepened his fascist apologetics. While Heidegger in Freiburg dreamt (unsuccessfully) of becoming the Nazi "thinker", Schmitt actually was-if fascism could be thought at all.

But how so, isn't there a contradiction or impediment to Nazi thought as such? The strength of fascism, after all, lies not in thought or theory but in action. As I have indicated, fascism is a movement, indeed, a mass movement, an enthusiasm, people united by shared feeling, submitting to the mesmerizing sway of an autocratic Dictator, galvanized by an exalting rhythmic rhetoric of a participatory and exclusionary social corporatism (under the banner of an always racist "nationalism" ${ }^{6}$ ) which infuses and gives grandiose meaning to lives otherwise ordinary, indeed, lives otherwise precarious, frustrated and discontented in view of the advances of a modernity which increasingly seems to render ordinary people superfluous. Fascist ideologues feed such anxieties and discontents, converting them into resentments, into victimhood; inventing and blaming vast but hidden cabals of enemies, traitors, backstabbers; stoking conspiracy theories; fueling pent up frustrations; and giving direction to the humiliated, the outcast and the miserable (despite their relative material prosperity). Also, consider that the moneyed elites, who have prospered from monopoly capitalism, fearful of public exposure are most fearful of socialist re-distribution, and make their beds with fascism, overcoming their distaste for its vulgarities, providing it financial and material support. But certainly also acting clandestinely, behind the scenes with "dark money", fearful of publicity or transparency. How then can fascism be thought of other than critically, antithetical as it is to thought itself?

Channeling a real but diffuse discontent, a discontent generated by the ubiquitous yet hidden and inevitable displacements effected by modernization, mechanization, Weberian rationalization, bureaucratization, globalization, the alienated and alienating impersonal administrative world so deftly invoked by Kafka, fascism gives expression to popular discontent, to negativity, by creating and blaming vampires, to be sure, but more reliably by enabling a discharge of frustrations and emotions, anything but clear or critical thinking. Through simplification, repetition, invention, through propaganda, yes, but above all by sanctioning violent passions and base emotions, fascism enables an emotionally satisfying discharge of mass frustration and dissatisfaction. Nothing is accomplished, treated or rectified, but at its mass rallies and in its sweeping rhetoric people feel relieved, they believe their frustrations having been recognized are therefore addressed. In appealing to passion and power, point by point fascism opposes Enlightenment, elevating will above mind, action above knowledge, intuition above reasoning, simplicity above complexity, obedience above freedom, command above questioning, the group above individuality, the uniform above the singular, and so on. Putting loyalty and obedience above freedom and truth, debate and criticism — any debate, any criticism—becomes acts of betrayal. Fascism, the will of the Dictator, is pathological narcissism empowered. And yet for all that, in view of its essential anti-intellectualism and anti-enlightenment, to the extent that fascism has attained a faithful theoretical expression, we find it in the apologia of Carl Schmitt. ${ }^{7}$

One can hardly miss that Schmitt is an apologue. But it must nonetheless be said and emphasized that he was a fascist supporter, indeed a Nazi, an official member of the Nazi party since 1933, because his adherence is not accidental or idiosyncratic but rather an expression, indeed a requirement of fascism, which holds no place-as Schmitt perfectly understood-for objective or outside observers and observation. There is really no disinterestedness, no "truth" of fascism for fascists—-there is only what fascists, or really the fascist Dictator, insists upon here and now. Fascism, like marriage, is only

6 For two brilliant studies of the political construction and use of "nationalism", see (Gellner [1983] 2006) and (Benedict [1983] 2006).

7 It has been said that the renowned German philosopher Martin Heidegger (who like Schmitt was a member of the Nazi party from 1933 to 1945, an antisemite, and likewise never criticized the Nazis or recanted anything after the war) wanted to serve and be recognized as the "thinker" of the Nazi movement. In fact, and not surprisingly, the Nazis found his ontological-poetic thinking obscurantist and his proffered loyalty suspicious. So, while it is sadly true that Heidegger's poetic thinking actually offered no resistance to Nazism, the Nazis never recognized it or him as their intellectual spokesperson, as in contrast they did Schmitt. 
experienced from within. Schmitt as an apologue understands that fascism allows no room or place for distantiation. It demands solidarity, loyalty and allegiance all the way. The truth is therefore what the Party says is true; and the Party says what the Dictator dictates. The news is what the Party says is news, what the Dictator wants to hear and to be heard. Beyond the Party line, beyond the Leader's outlook, all alternative perspectives are false, lies, fake, deception, indeed betrayal ${ }^{8}$. Orwell grasped this point perfectly with his notion, in 1984, of "doublespeak." It is false advertising applied politically, i.e., propaganda, in other words, reality determined by invention, a sort of aesthetics, the true and real being what the Dictator says is true and real. Schmitt joined the Nazi party in 1933, which one might be tempted to explain away as prudential or careerism, except that he was personally an antisemite, and he actively and without any publically or privately recorded reservation served the Nazi regime in several official positions. In 1933 he was appointed State Councilor of Prussia by Hermann Göring, Hitler's second in power, who was his protector. In November of the same year he became President of the Union of National-Socialist Jurists. This is not the place for a biography. Suffice to say that his fascism was not merely academic, theoretical or armchair, or prudential or careerist; rather it was his worldview, and consistent with his intellectual and literary apologetics for Nazi legal, social, political and military operations or, let us say forthrightly, consistent with his intellectual and literary apologetics for Nazi atrocities. Schmitt, in brief, was an active, willing and loyal Nazi, without any known reservations. That his Nazism was deeply held, indeed existential, and not merely prudential or opportunistic, is underscored by his decision after the Nazi defeat and in view of the American denazification program, to not recant anything, and instead (and of necessity) to leave public life for a comfortable retirement, during which time Schmitt continued unabated and unabashed to publish pro-fascist legal and political writings until his natural death in $1985 .{ }^{9}$ Yes, he was a monster, a defender of the evil and injustice of monstrous others, a monster whose writings, without outright saying so, defended the rapacity and mass murders committed by monstrous others, his Nazi overlords, but, we must add, a very intelligent, educated and articulate monster all the same. ${ }^{10}$

Schmitt's basic position is not difficult to discover or articulate, nor is it even new, since it is also the position of Machiavelli, Hobbes, Thrasymachus, and Calicles, and the position of all realpolitik, namely: "might makes right." In other words, power requires no justification beyond its own power. Whatever power can do, that is its right to do. To the extent that Schmitt lends his own inflection to this basic position, it has to do with the times, his historical situation. In post-Enlightenment modernity, intellectuals are rarely still orthodox theologians and are in any event rarely still awed by the transcendence of God or the majesty of kings or even by the authority of traditions. Political power thus no longer needs to pretend to such masks and justifications, and Schmidt accordingly no longer provides them. Power, one might say, is more brute, less devious, though for the public it will still be dressed in robes of religion and majesty. For Schmitt, however, as a theorist of power, political sovereignty is constituted by the will of the Dictator, period. The Dictator is sovereign, and sovereignty is dictatorship. All the masks are off, all the shame gone: power powers, as it were. Such, it seems, is the new inflection: the shamelessness of power.

In 1932, in The Concept of the Political, Schmitt is quite clear on this point, locating the essence or the energy, to be more exact, of the political in the Dictator's decision regarding who is friend and who is

$8 \quad$ See (Ellul 1965).

9 It is far more than irony, it seems to me, but rather like salt in wounds, to know that Carl Schmitt was able to live out his life in peace and prosperity in the same world where six million innocent Jews, including one million Jewish children, were tortured, starved, beaten and murdered; a world where tens of millions of other innocents and countless soldiers were murdered and/or killed, disposed, displaced, maimed, and injured, by the very murderous regime which he used all his considerable intellectual talents to aid and justify.

10 "Moderation in emotions and passions, self-control, and calm deliberation not only are good in many respects but even seem to constitute a part of the inner worth of the person. But however unconditionally they were esteemed by the ancients, they are far from being good without qualification. For without the principle of a good will they can become extremely bad, and the coolness of a villain makes him not only far more dangerous but also more directly abominable in our eyes than he would have seemed without it" (Kant 1959, p. 10). 
enemy. "The specific political distinction", he there writes, "to which political actions and motives can be reduced is that between friend and enemy"11. This idea, that the political boils down to deciding friend and enemy, and hence that no matter what regime or formalities are officially or legally in place, whether, for instance, government seems to be shared between executive, legislative and judicial branches; the political is ultimately, finally, really a matter of Dictatorial will or decisiveness-this fundamental claim serves as the centerpiece of Schmitt's entire political theory. ${ }^{12}$ Just as for the jurist Schmitt law is law and nothing else, untempered, that is to say, by ethical considerations, so too for the political theorist Schmitt the political is power and nothing else, also untempered by ethical considerations.

Given the centrality of this thesis, it is interesting to note that it is not Schmitt's original position. In his book of 1919, Political Romanticism, Schmitt reduced and attacked all contemporary political alternatives to fascism, especially liberalism, but also socialism, as mere Romanticism, because of their attachment to free speech, discussion and hence parliamentarianism, which Schmitt—owing to his decisionism-dismissed as empty chatter masking a deeper "inability to decide"13. He labels such politics Romantic for the same reason, because the Romantics are essentially indecisive aesthetes fluttering from one fashion to another, always stimulated and excited but never committed and engaged. However, in the same book, paradoxically, even while already affirming the centrality of decision, Schmitt writes that "the ability to make a decision between right and wrong .... is the principle of every political energy"14. That is to say, in his 1919 book he makes the decision upon which sovereignty is grounded an ethical decision, a matter of "right and wrong." Nor is this affirmation of the ethical character of decision-making found in just one passing remark, perhaps inconsistent, one might imagine, with his genuine position. A dozen pages later, Schmitt goes on to underscore the ethical dimension of the political altogether: "The most important source of political vitality", he writes, is "the belief in justice and an indignation over injustice"15. He says this to criticize the indecisiveness of the Romantics, not only because they are weak willed, but more specifically because they lack the ethical integrity to adhere to and uphold ethical belief and indignation. Such was Schmitt in 1919, in his book Political Romanticism; we will return to this peculiarity later.

In the following writings and the following years and indeed in all his subsequent work, hence more characteristically, really definitively, Schmitt drops ethics entirely. Politics and sovereignty is now entirely a matter of power, specifically of deciding friends and enemies according to the will of the Dictator alone. So in the Concept of the Political, dismissing ethics, along with all other standards external to power, Schmitt writes:

The political enemy need not be morally evil or aesthetically ugly; he need not appear as an economic competitor, and it may even be advantageous to engage with him in business transactions. But he is, nevertheless, the other, the stranger; and it is sufficient for his nature that he is, in a specially intense way, existentially something different and alien, so that in the extreme case conflicts with him are possible. These can neither be decided by a previously determined general norm nor by the judgment of a disinterested and therefore neutral third party. ${ }^{16}$

Fascism knows no general norms or disinterested judgments.

11 See (Schmitt 2007, p. 26).

12 It also lies at the basis of Schmitt's legal theorizing, which we are not considering here, but of which we can say, not surprisingly, that it defends pure formalism or legalism, because, of course, ethical questions are extraneous and allowed to play no role whatsoever. The law is what the written law says it is, and no more. The law equal justice because there is no other standard of justice. And the written law, in a fascist regime, far from establishing equality, is simply the record of the Dictator's will, unfettered by any acknowledgement of a universal humanity. The Nazis would have said it is "racial" law, though the meaning of "racial" was whatever was convenient that day.

13 See (Schmitt 1986).

14 (ibid., p. 116).

15 (ibid., p. 129).

16 See (Schmitt 2007, p. 27). In case one suspects Schmitt is not referring to ethical right and wrong, a few pages later he writes, distinguishing "taking sides", which is political, with free floating and merely Romantic rhetoric: "They do not propose to 
The application of ethical standards or the impingement of ethical responsibility in grasping the nature of politics, then, are erroneous and misleading distractions, as well being extraneous and dangerous because they obfuscate and needlessly obstruct what is the real business of politics, namely, power and nothing but power, getting things done, not explaining or justifying them-made real by the decisiveness of the Dictator.

But perhaps there is a historical explanation for Schmitt's earlier lapse in defending ethics as the energy or vitality of decision-making. Impressed as are all realpolitik advocates by success, perhaps he was briefly misled in Political Romanticism by the success of the Bolsheviks in Russia in 1917, a success that perhaps could be attributed in some serious measure to their claim to greater justice than their czarist and liberal democratic opponents. And then, just after the publication of Political Romanticism, Schmitt would have seen the success of the Italian fascists, who pretended to no such ethical claims for the "justice" of their cause, but based themselves primarily on nationalist sentiments. If political success guided his thinking, then Schmitt's subsequent books, and most obviously The Concept of the Political, published more than a decade later in 1932 after the Nazis proved their strength in German national elections, these would then reflect the victories of Italian and German fascism, unaided as they were by ethics, and indeed spurred as they were by their scorn for Enlightenment ethics and the Enlightened politics of liberal and social democracies especially.

In any event, rejecting and derisive of the ethics defended in his 1919 book, in all his subsequent work and most clearly in 1932 in The Concept of the Political, Schmitt came to the realization that while the political is indeed rooted in decision, as he has always thought, such decision at its core has nothing to do with choosing between right and wrong, justice and injustice, but everything and only to do with deciding as willing, deciding who is enemy and who is friend, but-and this is the key to fascism-with no criteria other than its own willfulness, which is to say with no objective criteria whatsoever. Whatever the historical reasons, such is the insight Schmitt propagates again and again and consistently thereafter, a Machiavellian insight radically opposed to Enlightenment and to ethics as such. Sovereignty lies in the Dictator who decides because he decides, who wills because he wills, end of story-no ethical criteria, no responsibility, no economic criteria, no criteria whatsoever. The political lies in the tautology, verbality or overpowering of power powering, and all the rest, all talk of justification and legitimacy is just that, talk, chatter, words masking what truly rules and is truly sovereign. Schmitt has only contempt for such talk, for debate, discussion, deliberation, and the like, which he derides, as did the fascists, as mere chatter, endlessly indecisive and pusillanimous.

This explains, too, why parliaments-literally "talking" places—with their deliberations are not only superfluous, the spinning of wheels without traction, but are actually dangerous obstructions to sovereignty. Talk never gets anything done, and fascism is all about doing, acting and moving. The denigration of discussion also explains why the Dictator needs no advice and consultation and cannot be questioned or criticized by anyone. Not, as the people will be deluded into believing by fascist propaganda, because the Dictator knows exactly what he is doing, or knows what is best, or is fulfilling a great master plan or destiny, but quite the reverse: Because he too has no idea why he wills this rather than that. The Dictator's will is arbitrary and must be arbitrary. This is not a fault for the fascist, but the highest virtue. The Dictator's will is a pure will, unchecked and unregulated by any exterior consideration beyond itself-like a god, like the God. Only as such is it a truly sovereign will. The Dictator can never be challenged, in other words, because there are no grounds upon which to challenge him. ${ }^{17}$ Thus any challenge, any criticism, no matter how rational, realistic or good willed, is by definition betrayal. The Dictator is Ubi Roi in flesh and blood. From the standpoint of all

take sides, which everyone has to do who speaks of good and evil in the moral sense and distinguishes right from wrong" (Schmitt 2007, p. 122).

17 So Denis Mack Smith emphasizes in his biography of Mussolini (Smith 1983): that Mussolini in preserving the integrity of his will isolated himself from the opinions of others and finally from an accurate picture of the contemporary military and political situation altogether, at Italy's peril. 
allegedly legitimizing authorities, whether ethical, populist, hereditary, religious, aesthetic, utilitarian, economic, or what have you, the Dictator's decision is beyond reproach. Force, power and might are the Dictator's first and final resort, and submission is the only appropriate response. Rule, call it law or not, is to dictate, order and command-hence the ubiquitous military trappings of fascism, however ludicrous, the Dictator wearing battle fatigues or dress uniforms adorned with medals, the pomp and ceremony, the military parades, and the displays of weapons in times of quiet as well as times of war. Without criteria or standards, the Dictator is sovereignty itself, no matter what he does or says-or the reverse, precisely in what he says and does, as he says and does it, always at the moment of his willing.

Fascism is in truth a constant state of war, repressive within and expansionist without, even when no specific police or military action is currently taking place. All non-fascist alternatives, non-fascist political parties and ideas and non-fascist states, to be sure, but also the freedom and creativity which make jokes, poetry, literature and cinema possible, are potential threats to its willful impositions. This is why Schmitt too understands sovereignty as a permanent "state of emergency" or "state of exception." Fascist sovereignty is arbitrary power normalized, violence and war normalized, without any actual norms. One day Trotsky is a friend, another day a traitor. One day Russia is the enemy, another day Russia is the friend, and sometimes it's the same day. Yesterday's truth is today's falsehood. Again, Orwell's 1984 well highlights the arbitrary shifting of alliances of fascism, where what alone counts is allegiance, in the moment.

\section{Critique of Schmitt}

The failings of Schmitt's outlook come to light when we situate his thought and its actions within three successively broader contexts: (1) political-economic, (2) theological-Christian, and (3) conceptual-philosophical. The first, the political-economic context, uncovers fascism's dialectical relations to liberalism, socialism and capitalism. While liberalism reflects early competitive capitalism, it falters in relation to late or monopolistic capitalism. Regarding the latter, socialism presents itself as the socially responsible corrective torchbearer, albeit anathema to unbridled capitalism. Given the latter, fascism serves the beneficiaries of big capital as a blunt alternative and violent diversion from socialism's proposed social democratic aufhebenf liberal democracy. The second, the theological-Christian context reveals Schmitt's implicit but untenable metaphysical dualism, while the third, the conceptual-philosophical context, reveals a hidden contradiction in the asymmetry of fascism's account of the relation between realpolitik and justice. In the present essay we have space only for the latter two contextualizations and criticisms, focusing primarily on the first, which is closest to the interests suggested by the name of the present journal ("Religions"), even if the political-economic context and criticism cuts deepest into the real and present dangers, indeed the disruption and overthrow of democracy and the terrorism which fascism manifests politically.

\subsection{Gnosticism's Hail Caesar}

Besides being a lawyer, a fascist theorist and a Nazi functionary, Schmitt was a believing Catholic. It is not this fact, however, that lies at the root of my criticism, although it perhaps has some biographical importance. Rather, our interest lies in the unavowed influence of a certain theological horizon, one of special importance for Christianity, past and present, specifically Gnostic metaphysics, which orients and distorts Schmitt's fascist apologetics, a horizon which he, for his part, would have his readers take to be purely political-theoretical and not religious-theological. We are indeed cognizant of its distorting political-theoretical consequences for Schmitt's fascism, but want here to acknowledge and examine its religious-theological origins and character, and hence in the following we treat the latter latter to shed more light on the former.

First we must clear up one way this religious horizon is not to be understood, or only inadequately understood. Schmitt readily admits a certain analogy between a key component of his legal and political theory and a key component of Christianity, namely the exception. "The exception in 
jurisprudence", he writes in Political Theology, "is analogous to the miracle in theology"18. That is to say, just as the omnipotent God of Christianity is said to have an Absolute Will capable of anything, all the way to what Kierkegaard called "the teleological suspension of the ethical", and all the way to miracles, so too the Dictator's will, or political sovereignty, is capable of overriding-as far as its power extends-all external restrictions of political power. Thus, Schmitt acknowledges an analogy between God's permanent state of exception and the Dictator's permanent state of exception, the one infinite and the other finite. Above, I too suggested this same analogy, but unlike Schmitt I presented it as a criticism of Schmitt's Dictator, the Dictator, always a human being, usurping the position of divinity, the Perfect One. What I want to bring to attention here, however, is something else, indeed almost the opposite point, though we shall see that it is not entirely unrelated. It is that Schmitt-proponent of realpolitik-carries through to the end the total divorce of political-public life from any higher ethical or spiritual calling, leaving the sphere of the political entirely and only to its own devises, which is to say as an imminent, differential play of forces, the realm of power. It is just in doing this, in this reduction of the political to power and to power alone that the influence-whether intentional or not-of Gnostic dualism is at work, that is to say, is consistent.

The separation of the political from everything else, especially from ethics and religion, but also from aesthetics, economics and utilitarianism, is, as we have seen in citation above, the actual ground of Schmitt's defense of Dictatorship and fascism. It is the ultimate ground of all realpolitik. Everything in Schmitt and fascism follows from such segregation. Schmitt's critique of all opponents to fascism for being Romantic, that is to say, occasionalist, is also based here. What is occurring here, what is at stake with this distinction, distinguishing an allegedly hardnosed realpolitik on the one side, divorced from ethics, religion, standards as such, and the latter-ethics, religion, standards, etc.—on the other, so that the latter are characterized as ineffectual, mere chatter, the nonsense of weaklings and the myopic? It is no great leap of thought to see that this distinction, really this separation, parallels the ancient metaphysical opposition of body and spirit, of body without spirit, pure power, i.e., the political, on one side, and spirit without body, pure mind, idealism and asceticism, on the other. And here then is our criticism: Both of these, body and spirit separated from one another, body without spirit, spirit without body, are intellectual abstractions, artificial constructions, products of a radically false and faulty metaphysics. Such dualism in fact represents a radical break with the two normative sources of Western political thought and practice, namely the ancient Greek tradition of Plato (despite "Platonism"), Aristotle and Thucydides, on the one hand, and the biblical prophetic tradition, including the long experience of the ancient Israelite Commonwealth, but also in Christianity, whose early Church fathers denounced Gnosticism (e.g., contra Valentinus, Marcionism), on the other hand, both of which always joined politics and ethics, seeing in politics the public social effort to embody and empower justice. So it seems to me that Schmitt's fascism is but a modern surreptitious revival of gnostic metaphysics, always a temptation to Christianity but one it rejected. But here is the most important point: Schmitt adopts a Gnostic metaphysics, however, not for the greater glory of God, but quite the reverse, to better indulge worldly powers, and to do so without pity or pang of conscience.

While Christian theology officially rejected the radically dualist metaphysics of Gnosticism, we must ask ourselves why this remains its greatest theological, and even more so, its greatest practical temptation. This requires a brief look at Christianity's origin, its early history and success, and its basic orientation. Paul, of course, and not Jesus, is the founding genius of Christianity. Jesus, after all, was born and died a Jew. Paul, in contrast, invented the dogmatic and institutional religion Christianity. In the tumultuous times of the first century CE, when Rome defeated Israel and put an end to the sovereignty of Israel's more than thousand-year-old Commonwealth. What Paul grasped first of all was what all Jews but extremist zealots also grasped, namely, that the Jews could not beat Rome militarily. He also understood that chastising Rome in the name of Jewish justice would be

18 See (Schmitt 1985, p. 36). 
little more than futile. Obvious, too, was that Jews could not join in Roman polytheism. What was to be done then? The smartest or perhaps the safest option-Paul's option-was simply to sidestep Rome. The basic orientation of Christianity, in contrast to Rome and to Judaism, would henceforth be spiritualization. Henceforth the "kingdom of God" would not be of this world but another, elsewhere, a spiritual world. Jesus would henceforth be the way out of this world to heavenly salvation-already it should be clear why and that Gnosticism will be such a religion's greatest spiritual temptation. Regardless, through spiritualization, Christians, unlike Jews, would not represent a threat to Rome. Jewish justice would always threaten Rome; Christian love, not at all. It took the Romans centuries to figure this out, but eventually they did. Looking past the pusillanimity and lowliness of Christians which disgusted the Roman nobility, Constantine realized that no religion more than Christianity would or could better serve Rome's imperial needs. Is this not, if we have ears to hear, what Constantine understood by his vision of the Cross bearing the motto "In this sign you will conquer" (In hoc signo vinces)? Christianity did not oppose Rome, it let Rome be. Indeed, it would never, it was pledged to never oppose Rome. So with Christianity as its religion, Rome would be free to conquer, free to unleash its powers; and to conquer and to manifest its power was of the very essence of Rome-now it would be blessed, sanctioned by its religion.

It is no accident, then, that Rome eventually absorbed Christianity and that Christianity became Roman, the sole official religion of the Empire. Not because the Emperors were "saved"-that is a Christian conceit-but rather because the Empire saw in Christianity acquiescence, the teaching of acquiescence, the teaching of obedience to Roman power. If the Christians had not written it themselves, the Romans would have had to invent Mark 12:17, attributed to Jesus: "Render unto Caesar the things that are Caesar's, and unto God the things that are God's." 19 It is Paul's genius to have made cowering and flight before power into religious virtues, to have made of worldly escapism a religious exaltation of spirituality. To be sure, this spiritualization meant a radical rejection of Judaism, for whom holiness was still worldly, concrete, historically bound, demanding of Jews the difficult struggle of world redemption for the sake of morality and justice, offering not personal or private salvation and spiritual peace but requiring the far more risky and difficult establishment of real peace, the end of real war, an end to swords, guns, bullets, bombs, mines, drones, cannons and armed combat. Judaism - its divine commandments, its prophets, its Talmud - is nothing but an insistence on justice in this world, here, now, always, for Jews, for everyone, especially "the widow, the orphan, the stranger", i.e., the least, those with least power, those most easily abused. Christian spiritualization, in contrast, would accept this world, accept its status quo, its kings, it tyrants, its powers, and turn the hearts, minds and souls of its faithful toward another world, a spiritual "kingdom", turning the cheek as Caesar has his way.

No doubt from the perspective of realpolitik, Christian political escapism represents a shrewd strategy of survival. Call it cowardly; call it irresponsible; such spiritualism preserves the Church and Christians by leaving evil and injustice to their own devices. We do not fear you, worldly powers, but you have no cause to fear us! No doubt, too, Christian otherworldliness broadens its popular appeal, not only because it plays to mystification and superstition, but more concretely because the ordinary run of humankind is little prone to moral heroism, and would rather be left well enough alone. In short, Christianity provides metaphysical justification for political indifference, for acquiescence in worldly powers. No wonder, then, that Rome, the Empire which crushed the Jewish Commonwealth—what Hannah Arendt called "the Roman trinity of religion, authority, and tradition" ${ }^{20}$ _eventually absorbed

19 A thousand years after Paul, of one of the most heated episodes of the great Investiture Controversy, Ekkehard (of Aura) in his Chronicles reports Pope Paschal II denouncing King Henry V face-to-face in Saint Peters in Rome citing this very verse. See, (Carlyle [1921] 1970, vol. IV), The Theories of the Relation of the Empire and the Papacy from the Tenth Century to the Twelfth, p. 123 (see there note 3). In addition to Mark 12:17, for Christian support of the political establishment, the status-quo, one could also cite Romans, chapter thirteen, whose first verse reads: "Let every person be in subjection to the governing authorities. For there is no authority except from God, and those which exist are established by God".

20 See (Arendt 1961). 
Christianity. In all probability, had Paulist Christianity not arisen, Rome would eventually have had to invent it, and in a certain sense it did invent it. The dualism between this world and the next, between the material world and the spiritual world, with religion choosing the latter and politics the former, this constitutive dualism and directive of Christianity is the same dualism-such is my contention-but now from the side of the material world, the earthly, the worldly powers, that undergirds Schmitt's political theorizing, the dualism which specifically enables him to defend fascism against its critics, which is to say, its ethical-moralizing critics.

The centerpiece of Christian politics, as I have indicated, is the abnegation of politics, or rather the feigned non-politics of rending unto Caesar the things that are Caesar's. I say "feigned" because such alleged non-politics in reality fully supports the politics of Caesar precisely by not opposing it. Not to oppose evil, not to oppose injustice, is to become complicit in each. Schmitt's political theorizing adopts the very same metaphysical frame as Christianity, but reverses its valence, opting for Caesar rather than God, standing Augustine's City of God on its head or tail. If religion is otherworldly, elsewhere, in heaven, then politics must be for the damned, the realm of damnation-and Schmitt fully and unabashedly realizing this, serves as a minion of Satan. Christianity leaves the world to Caesar; Schmitt's fascism-like Constantine's Empire earlier-takes it as such, as it is, putting being above the good. If salvation is primary, and salvation lies in heaven, then the earth is but a godforsaken cesspool, evil, the realm of sin-and so Schmitt and the fascists, confirming religion in reversing it valence, take it to be, and make it be.

What then does Schmitt say about the celebrated New Testament injunction found in Matthew and Luke that Christians must "love your enemies"? For fascism, the Dictator decides who is enemy and who is friend, and declared enemies are decidedly not to be loved. Notwithstanding, Schmitt is not troubled. "A private person", he writes, "has no political enemies"21. "The enemy in the political sense", he says elsewhere, "need not be hated personally, and in the private sphere only does it make sense to love one's enemy, i.e., one's adversary"22. It is the perfect escape clause. The Christian as Christian is a wholly spiritual person, a person who from the perspective of politics and political activism is purely private. Church and State do not meet, as spiritual and material do not meet. Thus, Christians should love their enemies, if they have enemies, but such enemies can never be, or can only coincidentally be political enemies. Political enemies, in contrast, must be hated politically, that is to say, treated as enemies-such is the obverse or dark side of Christian dualism. Ethics and religion, then, have no say in politics. What Schmitt neglects to mention is the totalitarian impulse of fascism, which because unbridled power is essentially restless and expansionist in fact conflates the private/public distinction, making everything a public affair, requiring allegiance to the State in all things, from cradle to grave, from procreation to conscience. Christianity, even willingly succumbing to the most radial Gnostic dualism, can never be otherworldly enough! No wonder Nazi German's Lutherans came to worship an Aryan Jesus, but were still disdained by the Nazis ${ }^{23}$.

In any event, interpreted politically, such escapism, whatever its own self-interpretations, is but the reality and the rationalization of non-resistance to power. It countenances any political regime, no matter how brutal or unjust. There is one positive side, however, that in fairness needs to be mentioned. Christian spiritualization, by distancing the Christian from the affairs of Caesar, while allowing Caesar his evil and unjust ways, which aim to be total within the fascist State, as I have emphasized thus far, insofar as that State is not fully totalitarian this same distantiation enables the Christian to love his neighbor-privately as Schmitt says—outside the sound and fury of political life. I am thinking here of those French and German soldiers of the Great War who interrupted the days and years of their muddy and bloody vicious trench warfare on 25 December to share Christmas toasts together in the no man's land between their lines. I call to mind also the "little kindnesses",

\footnotetext{
See (Schmitt 2007, p. 51).

(ibid., p. 29).

See (Heschel 2010).
} 
the old Russian woman who gives water to a dying German soldier during the Battle of Stalingrad, as described by Vasily Grossman in his great novel Life and Fate. Yes, these are unforgettable moments, noble irruptions of the holy, and cannot be lightly or really ever dismissed. But by the same token we cannot exaggerate their significance, because they do not alter the world of power, do not provide for the suffering of the many, the weak, the powerless, and leave the Dictators, the Masters, the Cruel to their evil devises. Noble as these instances are, to forsake the struggle for justice, in brief, is to renege on human responsibility, to lose sight of our shared humanity, and to give up on both politics and religion.

The critical point at hand is that the roots of Schmitt's fascism are not found in the political as such, but in the political predetermined by Paulist Christian theology, specifically the gnostic tendency of its metaphysical dualism, whereby Caesar is left to rule this world, a world predetermined as Satanic. We are not surprised, then, by Schmitt's intellectual allegiances, after Machiavelli and Hobbes, to three nineteenth century Catholic counter-revolutionary political thinkers: the papist Joseph de Maistre (1753-1821), the monarchist Louis de Bonald (1754-1840), and most of all the lessor known Juan Donoso Cortés (1809-1853), descendent of the conquistador Hernando Cortés, and the most radically conservative in politics and religion of the three. What might surprise us, however, but it should not, given Schmitt's modernity, is that contrary to the viewpoints expressed by these three reactionary precursors, who despite their own Christian fundamentalism resisted as heretical the gnostic tendency of Christian dualism by urging worldly powers to submit to the heavenly, king to pope, pope to God, Schmitt radically breaks with them precisely here, precisely regarding the necessity of some type of divine sanction for the political. Upping the ante of Enlightenment separation of Church and State, we might say, and therefore taking a path different than these three reactionary theologians, Schmitt drives to its logical conclusion the political consequences of the Gnostic tendency of Christian dualism, namely, affirming that this world is to be ruled absolutely in a worldly fashion, absolutely in the name of power and power alone, which is to say according to the unregulated will of the Dictator. It is thus as a thoroughgoing modern, it seems to me, that Schmitt discards all religious crutches, all masks, divorcing politics totally from any higher calling. In this lies his distinct contribution as a fascist apologue. He leaves the world, as he sees it, namely, as a world of powers, entirely and irrevocably to its own devises, power striving for more power, indifferent to morality, justice or holiness, as a power struggle to the end, the imperative of ever expanding Lebensraum become Gotterdammerung ${ }^{24}$. Such is the fascist glorification of war, and such are its upside down Gnostic premises.

\subsection{The Asymmetry and Primacy of Ethics}

To be sure, I oppose Schmitt as I oppose fascism. My opposition derives not only because its gnostic premises are specious and unjustifiable speculative fantasy, as they are, but more positively because in their stead I affirm morality, justice and holiness as legitimate demands of this world, of our shared world, a human world. My opposition to Schmitt and fascism, however, must not be misunderstood as one insistence posed against another, in an intellectual stalemate of name calling, on one side good on the other evil, or, from their point of view, on their a beyond good and evil-as if there were equity or parity. Rather, my claim is that to challenge Schmitt and fascism is greater, higher, better because they are self-contradictory in a very specific way: denying ethical politics with the same breath that they affirm it, even while they strain every chord and play every trick to hide their inconsistency. To show, as I aim to show, that Schmitt and fascism rely on ethics, indeed are the expression of an ethics, then their alleged absolute critique and dismissal of ethics must fall flat. They hoist themselves on their own petard. Of course this argument by itself, if taken as a "merely" intellectual exercise, cannot by itself end bullying, social abuse and viciousness, or realpolitik, but it can deflate the pretenses of fascism which support such behaviors. Such a deflation is surely one

24 See (Weiss 1967). 
positive and necessary step in the difficult and ongoing labor of opposing injustice and establishing justice-the always double task of an ethical politics.

I am not now referring to the shift we noted above between Schmitt's first book of political philosophy, Political Theology, published in 1919, and all of his subsequent work, the shift, that is to say, from his original claim that the political is rooted in a decisionism itself oriented by justice to his subsequent and more settled claim that the political is rooted in decisionism alone, decisionism without external standard, which is to say, that sovereignty lies in the unbridled will of the Dictator, end of story. What I am referring to presently is a contradiction in the latter claim, in Schmitt's settled claim that the essence of the political lies in power alone, that sovereignty is realpolitik, concretely the will of the Dictator, he who immanently and arbitrarily decides, based on will alone, who is friend and who is enemy, and that to think otherwise, to be a liberal or socialist, for instance, with all the attendant deliberation invoking moral justifications, is sheer Romantic fantasy with no traction in reality. To bring this contradiction to light we must clarify, first, the asymmetry of evaluation between ethical politics and realpolitik, and second, we must show that and how despite this asymmetry ethics retains primacy — and that it is precisely by denying this primacy that Schmitt's fascist theorizing contradicts itself.

What, then, is the fundamental asymmetry between fascism and ethics, between a politics based in power alone and a politics guided by justice? Each naturally views the other through its own lenses; all the sociologists, certainly Weber and Mannheim, have noted this, and treated it—as I will not—as an intractable relativism. So, to continue, for realpolitik, ethics is a mere epiphenomenon, a mass delusion, something without truth or substance, a fairy tale, though it does mystify and dupe the unwashed masses, and can be cynically utilized as such. The fascists do not see themselves as evil because they reject the dichotomy of good and evil entirely, seeing themselves as "beyond good and evil." Because the masses, in contrast, remain duped by ethics, the fascists use it in their propaganda; but for themselves, hardened by reality as they see themselves, they do not believe or succumb to ethical evaluations, and are unmoved by them. Fascism, in brief, has an insincere, hypocritical, ironic or really cynical relation to ethics: It is a propaganda tool, effective upon the weak minded, but without truth. Ethical politics, in contrast, takes ethics seriously, judging itself, judging the fascists, indeed judging all things social according to the valuations, the better and worse of ethics, hence for morality "good and evil" and for justice "just and unjust" or "right and wrong", and their verbal equivalents. The aim of ethical politics, specifically, is not power but justice. Justice means creating a world—conditions, behaviors and supporting procedures and institutions-whereby all humans can be moral to one another and respect the dignity of one another without fault. Politics, even more succinctly, is the regulation of power to serve justice. Thus, while fascists see ethical politics as nonsensical, unreal, Romantic, and themselves as beyond good and evil, ethical politics sees fascism as evil, unjust, violent, and abusive. But neither, and herein lies the depth of their asymmetry (and mutual hostility), accepts the standards of the other.

At first glance there seems to be no common ground and hence no basis for argumentation between realpolitik and ethical politics. If this were truly the case, if this were the final word, then the fascists would win, as it were, because only brute confrontation, violence and war could "relate" two mutually conflicting perspectives separated by an unbridgeable abyss. This is precisely Schmitt's contention: Politics is not a matter of debate, deliberation or argumentation, which are mere chatter signifying nothing, but a matter of will, resolution, decisiveness, and hence of power, of superior force, asserting and bending wills. One conquers and defeats one's enemies, one imprisons or executes traitors. Debate, deliberation, discussion, argument, criticism and their like, all these are but manifestations of indecisiveness, so when the moment of decision comes-and that moment is in fact a permanent state of affairs-all such talk is not only the expression of weakness and delusion, but as such it is also treasonous. We have seen this above. Returning to ethics, however, from the perspective of ethical politics, the brutality, violence, repression and war of realpolitik are in nowise great or glorious and are never justifiable by their victories alone, but rather are ethical horrors of arrogance, brutality and 
barbarism; horrors because they are immoral and unjust, and as such contemptible and deplorable, and subject to sanctions.

Given this asymmetry, these oppositions and their cross purposes, it is natural to ask why we charge realpolitik alone and not ethical politics with contradiction and self-deception. Is ethics not equally guilty of a self-validating circularity? Here lies the crux of the matter. Everything hinges on seeing why this is not so, why precisely in its effort to be beyond good and evil fascism reveals its fatal inner instability and fraudulence, deceiving — but ultimately unable to carry its deception all the way-itself and others.

According to Schmitt, as we know, political sovereignty lies in the Dictator deciding friend and enemy. The latter is not meant as an ethical decision. Nor is it meant as an aesthetic decision. Nor is it an economic, or utilitarian, or religious, or any other kind of decision, a decision within and guided by a larger context or standard. Rather it is meant as pure decision, pure power, unbridled, unregulated, "free" of any and every external criteria: The Dictator wills who is friend, who is enemy, and does so arbitrarily, based in willing alone. But for all its theoretical purity, is such an account accurate? What are we actually talking about, or is this just talk, empty talk? We must ask, in other words, if this how human willing actually transpires, Dictator or not? Do we not require a better phenomenology of willing than one determined by the peremptory presuppositions of absolute power politics? Surely we can say right away that the Dictator's will, like all human willing, is neither animal instinct nor mechanical necessity. Human will involves choice, something Schmitt acknowledges in his very use of the term "decision". And like all human choices, though it is not caused or necessitated by its environment, it is invariably influenced by multiple contexts, by past experience, by education, tradition, family, culture, language, geography, prospects, and so many other similar factors. The point at hand is that unless we wish to succumb to the supernatural it must be admitted that the Dictator's will is no different. It is not purely arbitrary, not miraculously independent of its context. To think of it as a pure unadulterated will is mere fascist propaganda, an intellectual construction, a fantasy really, even a Romantic fantasy, the Man with Superpowers, the God-Man, but without basis in reality, the reality realpolitik claims so much to reflect. No doubt fascists in fact do idealize and idolize their Leader, and do attribute to him superhuman qualities-but such wishful thinking and delusional projection does not make such qualities real. The point, very simply, is that it is not the liberal and socialist ethical politicians who are by nature romantics, mistaking fantasy for reality, but the fascists, with their fantasy of the arbitrary, unbridled, absolute will of the Leader. The fascist fantasy is precisely the idea of a non-ethical will, a pure will, a will based in willing alone. There is no such thing, not for ordinary people and not for the Dictator either. Willing, as choice, is always already in response to others within specific historical contexts, bound, that is to say, as Emmanuel Levinas teaches, within a web of responsibilities, and above all responsible to and for the other person, and ultimately to and for all others-hence always and necessarily ethical, whether it will evil or good. No doubt one can refuse one's responsibilities, refuse the other person, be evil, support injustice, and the like, and the fascists do and celebrate precisely that they do. But such refusals do not authorize or legitimate the invention and exaltation of a pure Decisionism without any basis in phenomenological reality.

The fascist fantasy of a non-ethical willing, the independent and resolute will of the Dictator, is also of a piece with the fantasy of Paulist theology, falsely dividing the universe between spiritless matter and immaterial spirit, when in fact, both are artificial constructions. Such dualisms-ungodly earth, angelic heaven, pure will, abject obedience-are fantasies of theology or speculative epistemology, and regardless of their political translations lacking basis in the real. Humans are from the first and are always in proximity with others, of mothers born and not posited, produced or manufactured. They exist within interpenetrating streams of temporality, as they exist in sensibility, memory and history, oriented by the height of the good and the inspiration of justice. Embodiment, temporality, language, family, community, economics, sociality, culture, and certainly politics, are all ethical formations, all permeated and fraught with imperatives of good and evil, justice and injustice. Humans are neither gods nor stones; escape is the delusion. Or as Levinas, borrowing from Rilke, 
has said: "Everything is serious" 25 . Or again: "Nothing is a game"26. Which is to say, even a game is not only a game.

Before concluding, I will restate this claim by way of Kant. At the end of the Critique of Pure Reason, Kant shows that science, the disinterested pursuit of truth, is not actually or entirely disinterested, but rather that its disinterest arises from and remains always in the service of a fundamental interest, namely, the interest in truth. The ground of disinterest, despite its self-interpretation to the contrary, is interest. But this interest does no undermine or disqualify its pursuit of truth, to the contrary. So, to restate this point, and Kant makes this claim explicitly: the ground of science is ethics. Far from undermining science this calls attention to its genuine ground, one that transcends the scientific notion of "ground" without undermining, to say it again, the legitimacy of the quest for truth. Such is Kant's claim at the end of the Critique of Pure Reason when he affirms the primacy not of knowledge, as his readers might have expected, but of ethics, which is the subject matter of his second critique, the Critique of Practical Reason. The necessities of truth depend on the freedom of the inquirer. "The very existence of reason", Kant writes at the end of the Critique of Pure Reason, "depends upon this freedom, which has no dictatorial authority" ${ }^{27}$. What this has to do with Schmitt, with the contradiction of realpolitik, and the primacy of ethical politics, is that just as science in restricting itself to disinterested inquiry remains driven by an interest in truth, so too in affirming willfulness in politics Schmitt also commits himself to ethics, to the free choice of better and worse, no matter how much or how loudly or subtly he may deny it, and no matter how much or how shamelessly he prefers evil and injustice. Schmitt chooses fascism. And in this choosing, in this non-fascist freedom, he at once undergirds but also ultimately undermines his fascism. So, too, the will or decision of the fascist Dictator, even at its most arbitrary or cruel, because it remains a human will, can never be completely arbitrary, never completely robotic or post-human, and as such is always within the reach and orientation of ethics. One judges and must judge the Dictator. The Dictator may jail or kill his opponents, but he cannot—including in his own person-eliminate ethics. That Schmitt and fascists choose evil and injustice does not free them of responsibility for their choices, or us of the responsibility to call them out and combat them.

We must not forget that just as bad art is still art, unjust politics, all the way to fascism, remains ethical politics. Nor can we be discouraged or disheartened by the historical fact that all political regimes fall short of the justice of which they are capable and toward which they are oriented. Such is also an essential and disturbing dimension of the political character of justice: that there is never enough of it. The world is not yet perfect-and this "not yet" is the very time of justice. When even our most just political regimes are not just enough, as they are not, and our leaders are never pure angels, which they never are, surely the unabashed evil and injustices of fascist Dictators and their heinous regimes must be combatted all the more. "This is why democracy", Levinas has said, "is the necessary prolongation of the State. It is not one regime possible among others, but the only suitable one. This is because it safeguards the capacity to improve or to change the law by changing-unfortunate logic!-tyrants, these personalities necessary to the State despite everything" ${ }^{28}$. Politics, like ethics itself, is difficult. ${ }^{29}$

\footnotetext{
See (Levinas 2003, p. 55).

See (Levinas 1998, p. 117).

See ((Kant 1998, p. 643 (A738/B766))).

See (Levinas 2001, p. 194).

2 Certainly readers of Levinas are familiar with his use of the term "difficult", in such expressions as "difficult freedom", "difficult justice" and even "difficult universality". Kant, already in "Idea for a Universal History with a Cosmopolitan Purpose", of 1784, had already underlined the difficulty of ethical politics: "The highest authority has to be just in itself and yet also a man. This is therefore the most difficult of all tasks, and a perfect solution is impossible. Nothing straight can be constructed from such warped wood as that which man is made of. Nature only requires of us that we should approximate to this idea"; in (Kant 1991, pp. 46-47). Regarding what Kant here characterizes as "impossible", Levinas will invoke the idea of "messianic time" (Totality and Infinity, p. 285) for a future of justice most desirable, for which one must struggle relentlessly, but also whose accomplishment is impossible to foresee today.
} 
The asymmetry of fascism and ethics, which fascism hypocritically exploits, does not conclude in decisionism or relativism, because it does not preclude ethics from having the first and last word. Though fascism's desired teaching, as Schmitt understood, is the tautology that "power makes power", or the awkward verbality of "power powers, we can hear it hypocrisy, its self-contradiction in the older and more common formula: "Might makes right." There is no escaping right. Ethics shows that even in the most vicious politics there lies choice, or to say this more precisely, that there is a being chosen, an election, an orientation toward the ethical better or worse. ${ }^{30}$ And this is why, it seems to me, the opening pages of Levinas's Totality and Infinity oppose peace to war, ethics to power, infinity to totality, and why on the closing pages of Otherwise than Being or Beyond Essence (Levinas 1998), Levinas sets the following political agenda: "The true problem for us Westerners is not so much to refuse violence as to question ourselves about a struggle against violence which, without blanching in non-resistance to evil, could avoid the institution of violence out of this very struggle" ${ }^{\prime 31}$. Politics is struggle, and includes violence, but there is a vast difference between what we can call good violence, i.e., violence used to end violence, and bad violence, i.e., violence for its own sake. The real struggle and difficulty of politics lies not in some imaginary escape from violence, but in choosing the right side, defending, deliberating as to the best way to protect and bolster the oppressed, the weak, the disadvantaged the suffering, the least, the powerless, and all those whose suffering calls out to us for help. Morality is difficult; justice is difficult. The State, as just as it may be, is never just enough, never. "Therein lies the very foundation of democracy", to cite Levinas one last time, in opposition to Schmitt. "One can debate decisions; there is no human decree that cannot be revised"32. Difficulty is neither necessity nor impossibility, nor is it an excuse. The difficulty of the good and of justice are rather prods.

Funding: This research received no external funding.

Conflicts of Interest: The authors declare no conflict of interest.

\section{References}

Arendt, Hannah. 1961. Between Past and Future. New York: World Publishing.

Benedict, Anderson. 2006. Imagined Communities: Reflections on the Origin and Spread of Nationalism. Brooklyn: Verso Books. First published 1983.

Capoutot, Johann. 2016. The Choreography of the End. In Greeks, Romans, Germans: How the Nazis Usurped Europe's Classical Past. Translated by Richard R. Nybakken. Oakland: University of California Press, pp. 357-91.

Carlyle, A. J. 1970. A History of Mediaeval Political Theory in the West, Volume IV. London: William Blackwood \& Sons. First published 1921.

Cohen, Richard A., ed. 1986. Face to Face with Levinas. Albany: State University of New York Press, pp. 1-10.

Ellul, Jacques. 1965. Propaganda: The Formation of Men's Attitudes. Translated by Konrad Kellen and Jean Lerner. New York: Random House.

Gellner, Ernest. 2006. Nations and Nationalism, 2nd ed. Ithaca: Cornell University Press. First published 1983.

Heschel, Susannah. 2010. The Aryan Jesus: Christian Theologians and the Bible in Nazi Germany. Princeton: Princeton University Press.

Kant, Immanuel. 1959. Foundations of the Metaphysics of Morals. Translated by Lewis White Beck. Indianapolis: Bobbs-Merrill Publishing.

Kant, Immanuel. 1991. Political Writings. Edited by Hans Reiss. Translated by H. B. Nisbet. Cambridge: Cambridge University Press.

30 A similar argument, but as an ethical critique of Heidegger's "hermeneutic circle," can be found in the "Introduction" to (Cohen 1986).

31 See (Levinas 1974, p. 177).

32 See (Levinas [1992] 2001, p. 183). 
Kant, Immanuel. 1998. Critique of Pure Reason. Translated by Paul Guyer, and Allen W. Wood. Cambridge: Cambridge University Press.

Levinas, Emmanuel. 1974. Otherwise than Being. Pittsburgh: Duquesne University Press, p. 177.

Levinas, Emmanuel. 1998. Otherwise than Being or Beyond Essence. Translated by Alphonso Lingis. Pittsburgh: Duquesne University Press.

Levinas, Emmanuel. 2001. In the Name of the Other. In Is It Righteous to Be? Edited by Jill Robbins. Stanford: Stanford University Press.

Levinas, Emmanuel. 2003. Humanism of the Other. Translated by Nidra Poller. Chicago: University of Illinois Press. Levinas, Emmanuel. 2001. The Awakening of the I. In Is it Righteous to Be? Stanford: Stanford University Press, p. 183. First published 1992.

Neumann, Franz. 2009. Behemoth. Chicago: Ivan R. Dee, Publisher.

Schmitt, Carl. 1985. Political Theology. Translated by George Schwab. Chicago: University of Chicago Press.

Schmitt, Carl. 1986. Political Romanticism. Translated by Guy Oaks. Boston: The MIT Press.

Schmitt, Carl. 2007. The Concept of the Political. Translated by George Schwab. Chicago: University of Chicago Press. Smith, Denis Mack. 1983. Mussolini: A Biography. New York: Random House.

Weiss, John. 1967. The Fascist Tradition. New York: Harper \& Row.

(c) 2018 by the author. Licensee MDPI, Basel, Switzerland. This article is an open access article distributed under the terms and conditions of the Creative Commons Attribution (CC BY) license (http:/ / creativecommons.org/licenses/by/4.0/). 